TecnoLógicas

ISSN-p 0123-7799

ISSN-e 2256-5337

Vol. 20, No. 40, pp. 125-138

Sep-dic de 2017

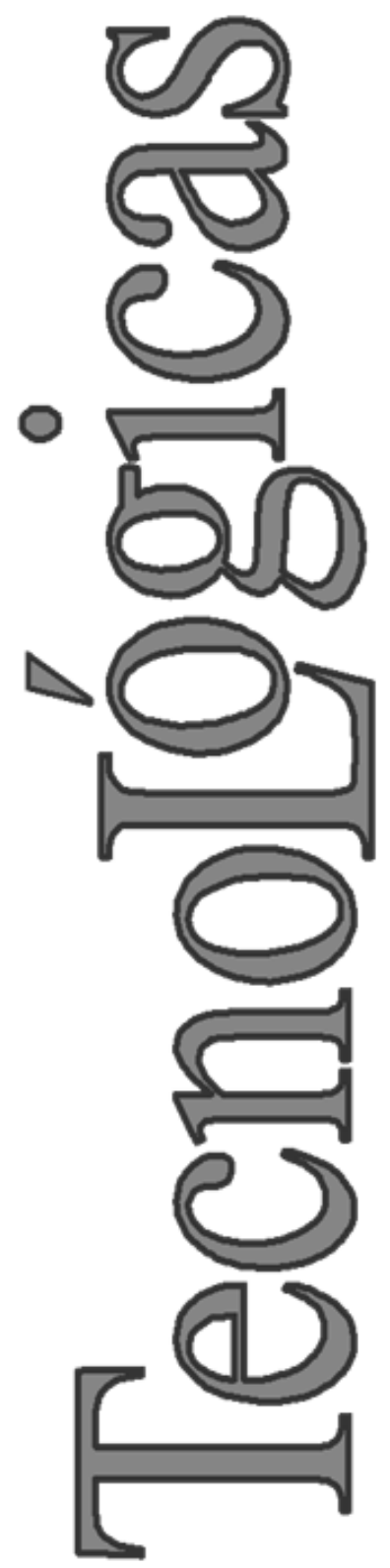

(C) Copyright 2015 por autores y Tecno Lógicas Este trabajo está licenciado bajo una Licencia Internacional Creative Commons Atribución (CC BY)

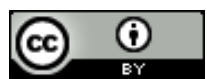

Artículo de revisión/Review paper

\section{Neurosurgery and brain shift: review of the state of the art and main contributions of robotics}

\section{Neurocirugía y desplazamientos cerebrales: una revisión del estado del arte y principales contribuciones desde la robótica}

\author{
Karin Correa-Arana ${ }^{1}$, Oscar A. Vivas-Albán² y \\ José M. Sabater-Navarro ${ }^{3}$
}

Recibido: 16 de junio de 2017

Aceptado: 15 de agosto de 2017

Cómo citar / How to cite

K. Correa-Arana, O.A. Vivas-Albán, y J.M. Sabater-Navarro, Neurosurgery and brain shift: review of the state of the art and main contributions of robotics. TecnoLógicas, Vol. 20, No. 40, pp. 125-138, 2017.

$1 \mathrm{PhD}(\mathrm{c})$. en Ciencias de la Electrónica, Facultad de Ingeniería Electrónica y Telecomunicaciones, Universidad de Cauca, Popayán-Colombia, kcorrea@unicauca.edu.co

2 PhD. en Robótica, Facultad de Ingeniería Electrónica y Telecomunicaciones, Universidad de Cauca, Popayán-Colombia, avivas@unicauca.edu.co

3 PhD. en Robótica, Departamento de Ingeniería de sistemas y Automática, Universidad Miguel Hernández de Elche, Elche-Alicante-España, j.sabater@goumh.umh.es 


\section{Abstract}

This paper presents a review about neurosurgery, robotic assistants in this type of procedure, and the approach to the problem of brain tissue displacement, including techniques for obtaining medical images. It is especially focused on the phenomenon of brain displacement, commonly known as brain shift, which causes a loss of reference between the preoperative images and the volumes to be treated during image-guided surgery. Hypothetically, with brain shift prediction and correction for the neuronavigation system, minimal invasion trajectories could be planned and shortened. This would reduce damage to functional tissues and possibly lower the morbidity and mortality in delicate and demanding medical procedures such as the removal of a brain tumor. This paper also mentions other issues associated with neurosurgery and shows the way robotized systems have helped solve these problems. Finally, it highlights the future perspectives of neurosurgery, a branch of medicine that seeks to treat the ailments of the main organ of the human body from the perspective of many disciplines.

\section{Keywords}

Neurosurgery, brain shift, medical robotics, neuronavigation, minimally invasive surgery.

\section{Resumen}

Este artículo presenta una revisión acerca de la neurocirugía, los asistentes robóticos en este tipo de procedimiento, y el tratamiento que se le da al problema del desplazamiento que sufre el tejido cerebral, incluyendo las técnicas para la obtención de imágenes médicas. Se abarca de manera especial el fenómeno del desplazamiento cerebral, comúnmente conocido como brain shift, el cual causa pérdida de referencia entre las imágenes preoperatorias y los volúmenes a tratar durante la cirugía guiada por imágenes médicas. Hipotéticamente, con la predicción y corrección del brain shift sobre el sistema de neuronavegación, se podrían planear y seguir trayectorias de mínima invasión, lo que conllevaría a minimizar el daño a los tejidos funcionales y posiblemente a reducir la morbilidad y mortalidad en estos delicados y exigentes procedimientos médicos, como por ejemplo, en la extirpación de un tumor cerebral. Se mencionan también otros inconvenientes asociados a la neurocirugía y se muestra cómo los sistemas robotizados han ayudado a solventar esta problemática. Finalmente se ponen en relieve las perspectivas futuras de esta rama de la medicina, la cual desde muchas disciplinas busca tratar las dolencias del principal órgano del ser humano.

\section{Palabras clave}

Neurocirugía, desplazamiento cerebral, robótica médica, neuronavegación, cirugía mínimamente invasiva. 


\section{INTRODUCTION}

Since the ancient beginnings of neurosurgery-with trepanations known since thousands of years BC and particularly since the 1980s with the emergence of current neurosurgery techniques-the requirements for good surgery have become stricter and stricter, thus reducing the surgical field, limiting damage to healthy tissues, and attempting to preserve the functionality (and connectivity) of brain tissues. The need for precision and microscopic scales has made neurosurgery a clinical domain receptive to the use of robotic tools [1] and [2]. Robotic neurosurgery is undergoing deep changes in recent times, mainly resulting from advances in medical imaging techniques (CT, MRI, fMRI or DTI) enabling better planning the surgical operation to be performed, [3] and [4]. However, during the medical procedure, the brain shifts and deforms (a phenomenon known as brain shift) because of several factors: loss of cerebrospinal fluid (CSF), the action of gravity, the size and location of the surgical target, resections and drug administration, among others [5][7]. Consequently, the spatial relationships and planning of the neurosurgery with preoperative images are altered. As a result, navigation accuracy during the procedure is reduced and the surgeon cannot fully rely on the spatial information provided by the navigation system [8]. At present, much research is carried out in the world in order to correct brain shift and try to transfer the pre-established work plan to the intra-operative reality in neurosurgery [9]-[13].

The aim of this article is to present a review about the problem of displacements suffered by brain tissue during neurosurgery, and to show the evolution of this procedure thanks to the applications of robotics and medical imaging modalities. The article begins with the general aspects of neurosurgery. Later, it mentions the robotic systems used to perform the proce- dures. Afterwards, the brain shift phenomenon is presented and analyzed, revealing aspects of the collection of information (medical images and others) during the preoperative and intraoperative stages that are affected by brain shift. Next, future perspectives in neurosurgery are presented, taking into account robotic systems as well as brain shift prediction and correction.

\section{NEUROSURGERY}

Neurosurgery deals with the diagnosis, treatment (intervention) and post-surgical rehabilitation of patients with central nervous system injuries [14]. Stereotactic neurosurgery has allowed for several surgical procedures such as biopsies, hematoma evacuation, drug delivery, surgical resection, SEEG (radiosurgery stereoelectroencephalography) and DBS (deep brain stimulation), among others. All these procedures, known as keyhole surgeries, have in common a trepanned entrance hole in the exterior of the skull [15].

Recent improvements in medical imaging techniques have led to major advances in neurosurgery. The combination of new imaging modalities and neuronavigation systems provide neurosurgeons with the ability to accurately visualize the surgical anatomy and locate the pathology during a procedure. For instance, an optimal trajectory can be selected prior to the operation to minimize the invasiveness of the neurosurgical procedure and to prevent perforation of functional neural tissue. In addition, the combination of neuronavigation and other imaging techniques allow to improve the identification and location of critical structures adjacent to the edge of a lesion, thus avoiding damage to these areas during removal [16] and [17]. Minimally invasive neurosurgery (MIS) benefits from these advances [18]. MIS refers to surgeries performed through small incisions (or using natural orifices) to minimize trauma 
to the body as well as to reduce patient recovery time and hospitalization costs [19] and [20].

Since some years ago, diverse teams of neurosurgeons have performed minimally invasive surgeries to achieve better results compared to open (invasive) surgical procedures [21]. A clear example of MIS is endonasal endoscopic surgery. It offers neurosurgeons a minimally invasive surgical technique for procedures in the cranial base in which specific surgical instruments and an endoscope are inserted through the patient's nostrils. This procedure is known as EEA (endoscopic endonasal approach) [22]-[24]. Fig.1 shows the focus of an EEA procedure.

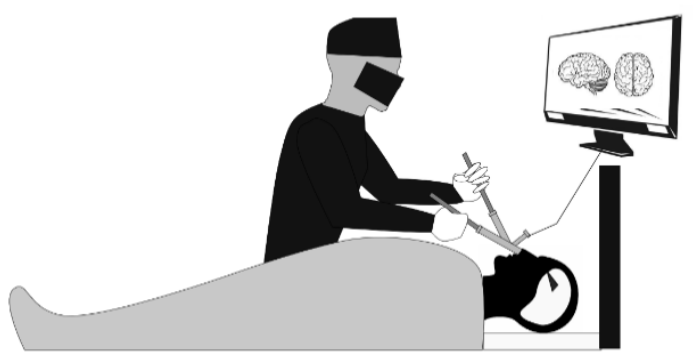

Fig. 1. Minimally invasive surgery by endonasal approach. Source: Authors.

However, in this type of approach, the neurosurgeon's movements must be controlled and precise given that critical anatomical structures coexist in the operative field. In addition, the three-dimensional view the surgeon has in open surgeries is lost. Likewise, in this approach the efforts exerted on the surroundings of the nostrils should be minimized due to their greater rigidity and the delicacy of their tissues [25]. There are also difficulties such as video camera positioning control, ergonomic difficulty in the surgical procedure, surgeon training, loss of tactile sensation of the patient, and lack of rotation of the physician's wrist joint [26]. There is also a great disadvantage in neurosurgery related to the deformable nature of living tis- sue, which is mentioned and studied by various clinical and research teams [27][29]. During surgery, the deformation and displacement of the brain tissue alter the spatial relationship between the patient and the volumes of preoperative images, resulting in location errors. This phenomenon is commonly known as "brain shift" [25]. The opening of the skull and dura mater, loss of cerebrospinal fluid, reduction of intracranial pressure and placement of surgical devices during neurosurgery contribute to intraoperative cerebral deformation [30]. The surface of the brain can deform up to $20 \mathrm{~mm}$ after the skull is opened; also, resection of large lesions can increase the deformation of brain structures, even up to $50 \mathrm{~mm}$ [31]. Despite all the advances made over recent decades in the field of cerebral imaging, brain shift still causes a significant decrease in the accuracy of the commercially available neuronavigation systems that record the preoperative images to carry out intraoperative location of tumors or other lesions [32].

On the other hand, neurological morbidity is of great importance because the brain, the spinal cord and the peripheral nerves exert total control over the neurological functions of the whole body. That is why the injuries that affect these structures have huge physical, psychic and social repercussions [33]. This situation has led to studies of the most common neurological pathologies [34] in many countries, which has helped to improve neurosurgery planning protocols as well as the care of and intervention in patients suffering from these conditions [35].

\section{ROBOTICS IN THE NEUROSURGERY FIELD}

In general, as mentioned above, there are several difficulties in neurosurgery: limited degrees of freedom on the part of the neurosurgeon, loss of depth perception, 
lack of flexibility to reach anatomically complicated spots, downward drift, and brain shift, among others [14]. Due to the problems in this field, robotic systems have been used to solve some of them. The use of robotics in surgery has grown exponentially for the last 15 years; its greatest contribution is made in orientation and positioning of surgical instrumentation, greater degrees of freedom, superior threedimensional view, improved resolution, elimination of trembling, scaling of the neurosurgeon's movement, and imposition of physical restrictions to avoid delicate areas [36]. Robotic surgery has opened a new era in minimally invasive procedures (avoiding in some cases the need for open and morbid approaches) which in turn can improve functional outcomes [19] and [37].

Robotized systems such as SurgiScope, Neuromate, Rosa, and others have enabled the modification of neurosurgical procedures, mainly due to the introduction of image-guided surgery [38]. Table 1 summarizes different contributions of the field of robotics to neurosurgery. Many of these contributions have resulted in commercial products currently in use. Table 1 shows that there are different approaches with different mechanical designs of robotic systems. However, only three types of control architectures can be found, as follows. i) Supervised control: The surgeon plans the movements of the robot off-line and, during the operation, the robot moves autonomously under the supervision of the doctor. ii) Tele-operated control: The slave robot is controlled by the remote manipulation of a master device operated by the neurosurgeon, usually with force feedback capability. iii) Shared control: Both the robot and the surgeon have control over the surgical instruments. The surgeon controls the surgical procedure and the robot is also used as a limitation to the movements of the hands of the former to avoid tremors and improve safety on delicate surgical areas.
The robotized systems (mentioned in Table 1) have allowed the improvement modification of procedures associated with neurosurgery by making use of medical imaging guides during the procedure [48]. Several clinical teams have performed surgical operations with access to the base of the skull through the nasal fossa [22-24] and [49] using Intuitive Surgical's commercial system, Da Vinci: a generalpurpose teleoperated surgical robotic system. Several advantages are described in works with this robot. They include the use of the robot for accessing the base of the skull and its possibility of reconstruction, sealing the dura mater after the operation, absence of trembling and the advantage that scaling offers in the tele-operation scheme. However, a disadvantage is the use of a large-scale system that causes an excessively invasive procedure while not allowing access to all areas, such as the ethmoid bone or the anterior cranial fossa. Other neurosurgery assisting robots focus on the location of electrodes in deep brain areas and on shared control for craniotomy, but few of them on endoscopic management of the endonasal approach. Also, there are brain lesions at the base of the skull such as pituitary tumors, chordomas, craniopharyngioma, cysts or meningiomas that are difficult to access using the techniques mentioned above [50].

Nevertheless, there is still room for improvement, particularly in terms of cost reduction and the development of smaller and more powerful robotic systems [3], [51] and [52].

Despite the great advances in the field of robotic neurosurgery, problems related to the deformable nature of the biological tissues involved-which cause difficulties in the use of classic schemes of humanrobot control and interaction-are still the object of recent research [53]. In addition, it would be desirable for robots assisting neurosurgical tasks to incorporate a neuronavigation system that provides updated information on cerebral displacements. 
Such system might predict and estimate brain shifts by using finite element models that are fed intraoperative signals from ultra sound or radio frequency sensors. This way, the assisting robotized system would have reliable information about the location of the spots to be treated during surgery (taking into account brain shift) and hypothetically the results of medical procedures would be better. The brain shift phenomenon is presented in detail below.

\section{BRAIN SHIFT IN NEUROSURGERY}

Brain shift is the geometric transformation the brain undergoes during the course of the operation; all the structures of this organ and, therefore, the locations to be treated in the intervention are completely displaced. This results in a loss of reference with respect to the volumes of neurosurgical images acquired in the preoperative phase. There are two main reasons for this brain shift. First, the opening of the dura mater (a membrane that covers and protects the brain) causes large nonlinear deformations due to pressure changes and cerebrospinal fluid loss, [54] and [55]. The surgical procedures of resection, cuts or excision are the second cause [56]. Different authors argue that brain shift is one of the greatest causes of failure in neurosurgical procedures with neuronavigation systems [8] and [57]. Fig. 2 shows the brain shift phenomenon.

Table 1. Robotic systems and projects used for applications in neurosurgery. Source: Authors.

\begin{tabular}{|c|c|c|c|}
\hline Project & Current Status & Type of Control & Comment \\
\hline Da Vinci [3] & $\begin{array}{l}\text { Commercial product } \\
\text { (Intuitive Surgical, } \\
\text { Sunnyvale, CA, USA) }\end{array}$ & Tele-operated & $\begin{array}{l}\text { Recently used for head and neck surgery } \\
\text { (ear, nose and throat - ENT). }\end{array}$ \\
\hline NeuroArm [39] & Research project & Tele-operated & $\begin{array}{l}\text { Multi-robot system designed to work } \\
\text { with intraoperative MRI. }\end{array}$ \\
\hline RoboCast [40] & Research project & $\begin{array}{l}\text { Supervised/ } \\
\text { Tele-operated control }\end{array}$ & $\begin{array}{l}\text { Multi-robot system for neurosurgery } \\
\text { without a stereotactic frame or guide. }\end{array}$ \\
\hline Renaissance [41] & $\begin{array}{l}\text { Commercial product } \\
\text { (Mazor Robotics Ltd., } \\
\text { Caesarea, Israel) }\end{array}$ & Supervised control & $\begin{array}{l}\text { Small Stewart-Gough platform (parallel } \\
\text { robot) to be placed over the patient. }\end{array}$ \\
\hline SurgiScope [42] & $\begin{array}{l}\text { Commercial product (ISIS } \\
\text { Robotics, Saint Martin } \\
\text { d'Heres, France) }\end{array}$ & Supervised control & $\begin{array}{l}\text { Delta parallel robot to carry the micro- } \\
\text { scope. }\end{array}$ \\
\hline NeuroMate [43] & $\begin{array}{l}\text { Commercial product } \\
\text { (Renishaw-Mayfield SA., } \\
\text { Nyon, Switzerland) }\end{array}$ & Supervised control & $\begin{array}{l}\text { Serial robot with navigation based on } \\
\text { computerized tomography images. }\end{array}$ \\
\hline Rosa [44] & $\begin{array}{l}\text { Commercial product } \\
\text { (MedTech SA., Montpel- } \\
\text { lier, France) }\end{array}$ & $\begin{array}{l}\text { Supervised/ } \\
\text { Shared control }\end{array}$ & $\begin{array}{l}\text { Robot manipulator with shared control } \\
\text { and image-based planning module. }\end{array}$ \\
\hline NeuRobot [45] & Research project & Supervised control & $\begin{array}{l}\text { Robot with four degrees of freedom for } \\
\text { manipulating an endoscope. }\end{array}$ \\
\hline PathFinder [46] & $\begin{array}{l}\text { Discontinued commercial } \\
\text { product (Prosurgics Ltd., } \\
\text { High Wycombe, United } \\
\text { Kingdom) }\end{array}$ & Supervised control & $\begin{array}{l}\text { Serial robot with navigation based on } \\
\text { optical markers. }\end{array}$ \\
\hline Evolution I [47] & Discontinued & Tele-operated & $\begin{array}{l}\text { Hexapod robot with four degrees of } \\
\text { freedom. }\end{array}$ \\
\hline
\end{tabular}




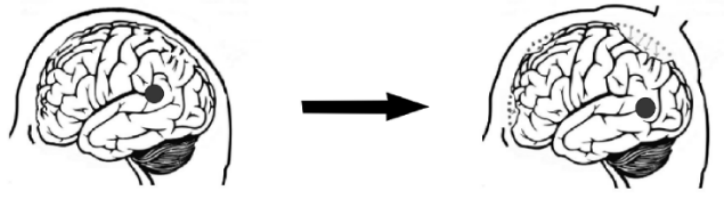

Fig. 2. Brain shift caused by the opening of the dura mater. Source: Authors.

Intraoperative imaging technologies that use magnetic resonance imaging (iMRI) [58], computed tomography [59] and ultrasound [60] have been shown to be beneficial for resection control as well as detection of brain changes [1]. iMRI in particular offers a very convenient solution to obtain several surgically relevant parameters such as the location and edge of the tumor as well as functional brain parameters (e.g., blood flow perfusion and chemical composition) [61]. Currently, the main way to deal with the brain shift problem during neurosurgery is the use of intraoperative magnetic resonance imaging. Nevertheless, intraoperative imaging techniques are classified as invasive methods, since the body is exposed to the harmful effects of magnetic fields and X-rays [62]. In addition, neurosurgery rooms equipped with iMRI are not very common in the vast majority of hospitals because of their high cost and the fact that all surgical instruments and anesthesia equipment must be suitable to be used in such an environment [16]. Another aspect to keep in mind is that, with the use of iMRI, the time of each scan extends by about $20 \mathrm{~min}$ [63] and the flow of information can be interrupted during the neurosurgery [25].

Several authors have proposed solutions to address the problem of brain shift. In [64], Letteboer and his group propose the use of a 3D ultrasound system to obtain an image of the brain volume. This work uses a 3D ultrasound probe, superimposing the information of the ultrasonic waves on a rigid pre-operative model obtained by magnetic resonance imaging. Differences between solid tissues and hy- perechogenic structures have also been used to study the brain shift phenomenon [65]. Uff and his team [66] extend the use of the ultrasound signal to generate elastograms that enable the visualization of differences in the biomechanical characteristics of tissues, so that healthy and damaged tissue can be differentiated. Nonetheless, they do not detail the process to acquire the ultrasound data. Other approaches have made use of optical systems [40] to "track" anatomical points. However, the limitation of this approach is that the marker should be visible. Even more interesting are the approximations that make use of a mathematical-physical model of deformations to predict the displacements of all points of the brain [54] and [55]. But they require a model validation process which is often not easy to carry out due to the difficulty of measuring the actual displacements to check the generated model [56]. On the other hand, the input information for the model is provided by the displacements of the points that are measurable (visible) by optical methods, which produces an important bias in the input data. Other authors adopt a method to integrate retraction modeling into neurosurgery by using a framework based on atlas deformations (a set of possible deformations predicted by a biomechanical model) to compensate for the brain shift effect [55]. Table 2 presents a summary of the most recent studies regarding brain shift.

As can be seen in Table 2, a growing number of authors have begun to investigate the possibilities of correcting brain shift change during neurosurgery [64]. Computational modeling methods, such as finite element analysis [54] and [79], are often used and combined with intraoperative image data to provide a brain shift compensation strategy. Efforts are also being made to address the complex issues of living tissue (brain) modeling and obtaining information about its response to 
Table 2. Recent research works regarding brain shift in neurosurgery. Source: Authors.

\begin{tabular}{cl}
\hline \multicolumn{1}{c}{ Project } & \multicolumn{2}{c}{ Research Center } \\
\hline The mechanics of decom- & Stanford University, \\
pressive craniectomy [67] & $\begin{array}{l}\text { Exeter University and } \\
\text { Oxford University }\end{array}$
\end{tabular}
This work presents a computational craniectomy model that helps to quantify brain shift, axonal stretching and shearing. The study allows to infer or identify (personalized) high-risk regions vulnerable to brain damage during the surgical procedure.

A combined registration and finite element analysis method for fast estimation of intraoperative brain shift [68]

\section{Tehran}

University of Medical

Sciences This study proposes a combination of preoperative and intraoperative information registration. It uses optimized algorithms in a piece of software for analyzing finite elements, which enables to shorten the calculation procedures of volumetric deformation. The authors of the study hope that the proposed method will accelerate the overall brain shift estimation procedure.

Estimation of intraopera- Ryerson University and tive brain shift by combination of stereovision and Tehran University The authors of this study propose a new combination of superficial images and intraoperative doppler images to calculate the displacements of the cortical surface and the deformation of the internal vessels. They estimate the brain shift using a finite element model (FEM).

doppler ultrasound [69]

In this study, the authors evaluate the robustness and

Clinical evaluation of a Vanderbilt

model updated image University and Memori-

guidance approach to al Sloan Kettering precision of a biomechanical model for brain shift correcbrain shift compensation Cancer Center [70]

Anticipation of brain shift in deep brain stimulation automatic planning [71]

University of Strasbourg and others tion that was developed for tumor resection surgery.

Evaluation of conoscopic holography for estimating tumor resection cavities [72]

Near real time computer assisted surgery for brain shift correction using biomechanical models [73]

A projected landmark
method for reduction of
registration error in
image guided surgers
systems [74]

Real time nonlinear finite element computations on GPU application to neurosurgical simulation [75]

\begin{tabular}{|c|c|c|}
\hline $\begin{array}{l}\text { A brain deformation } \\
\text { framework based on a } \\
\text { linear elastic model and } \\
\text { evaluation using clinical } \\
\text { data [76] }\end{array}$ & $\begin{array}{l}\text { Digital Medical Research } \\
\text { Center, Shanghai Medi- } \\
\text { cal School, and others }\end{array}$ & $\begin{array}{l}\text { In this project, the authors implement and evaluate a } \\
\text { model based on linear elasticity for brain shift correction } \\
\text { using clinical data from five brain tumor patients. }\end{array}$ \\
\hline $\begin{array}{l}\text { Doppler ultrasound } \\
\text { driven biomechanical } \\
\text { model of the brain for } \\
\text { intraoperative brain shift } \\
\text { compensation: a proof of } \\
\text { concept in clinical condi- } \\
\text { tions [77] }\end{array}$ & $\begin{array}{l}\text { Joseph Fourier Universi- } \\
\text { ty and British Columbia } \\
\text { University }\end{array}$ & $\begin{array}{l}\text { This work presents a neuronavigator that approaches the } \\
\text { subject of brain shift and offers passive help to the surgeon } \\
\text { by visualizing the position of guided tools with respect to } \\
\text { the corrected location of the tissues. The authors argue } \\
\text { that tumor resection is the cause of most intraoperative } \\
\text { brain shifts and, therefore, its modeling is the next chal- } \\
\text { lenge in neuronavigation based on biomechanical models. }\end{array}$ \\
\hline $\begin{array}{l}\text { A sparse intraoperative } \\
\text { data driven biomechani- } \\
\text { cal model to compensate } \\
\text { for brain shift during } \\
\text { neuronavigation [78] }\end{array}$ & $\begin{array}{l}\text { Shanghai Neurosurgical } \\
\text { Center and others }\end{array}$ & $\begin{array}{l}\text { This project presents a brain shift calculation based on a } \\
\text { linear elastic model and its implementation in the } \\
\text { 3DIMAGE system (developed by the same research group). } \\
\text { The precision of the brain deformation compensation of } \\
\text { this model was validated with real-time image data ac- } \\
\text { quired from the PoEStar system. }\end{array}$ \\
\hline
\end{tabular}
Vanderbilt This study investigates the use of a low-cost acquisition University Vanderbilt University In this paper, the authors present the development of a Medical Center

The authors present an automatic planning approach for deep brain stimulation (DBS) procedures that takes into account brain deformation. They present an optimized FEM algorithm that includes brain shift simulation. method to measure brain shifts produced by the resection of a tumor. The method is based on the principle of conoscopic holography. new line of preoperative and intraoperative computational processing for brain shift correction in almost real time (automating and simplifying processing steps). University of Western

\section{Australia}

Image-guided surgery systems are limited by the registration error, so it is necessary to use practical and effective methods to improve accuracy. In this project, the authors develop and test a method based on the projection point to reduce superficial registration error in guided image surgery.

The aim of this study is to significantly increase the efficacy and efficiency of image-guided neurosurgery by including realistic brain shift calculus using a completely nonlinear biomechanical model.

In this project, the authors implement and evaluate a model based on linear elasticity for brain shift correction using clinical data from five brain tumor patients. quired from the PoEStar system. 
different loading conditions [80]. Researchers are also working to develop sophisticated computational models with general anatomical information and complex structural information (e.g., aided by diffusion tensor images and elastography) [81]. In addition, multiphysics platforms are being developed for modeling; they incorporate a variety of constitutive laws as well as interactive simulation conditions, including nonlinear deformation effects (e.g., SOFA) [73].

Modeling cerebral displacement from preoperative and intraoperative information provided to measure the brain shift effect during surgery is important if you understand that the developments in this field are minimal compared to other studies in medicine and that they can hypothetically be a solution that leads to precise surgical navigation, in which trajectories can be planned to minimize the damage to healthy tissues during neurosurgery [82].

\section{PERSPECTIVES IN NEUROSURGERY TAKING INTO ACCOUNT ROBOTICS AND BRAIN SHIFT}

The panorama of neurosurgery is constantly evolving; its challenging mission is reaching all corners of the nervous system. Advances in robotics, modeling of brain tissue behavior, and imaging-guided surgery techniques are expected to allow for great achievements in this field [83]. In terms of future perspectives, robotic systems are expected to provide the neurosurgeon with greater assurance during the intervention, including assistance in the form of automatic, collaborative, or shared-control movements, as well as augmented reality.

A research team with members of three Spanish universities are working on a robotic system that adapts to the ergonomics of the neurosurgical intervention. Therefore, accurate surgical navigation can be relied upon based on online information to measure the effect of brain shift, while taking into account preoperative planning. Also, this system is expected to have an automatic surgical tool exchanger. This way, the robotic system seeks to incorporate-into a fault-tolerant cognitive architecture-a movement control system that avoids damage to the nasal fossa, a collaborative movement planner with learning ability, and a mathematicalphysical model for predicting threedimensional displacements of the brain based on intraoperative information.

It is noteworthy that the proposal of the Spanish group seeks the integration of two innovative concepts in robotic neurosurgery: a collaborative surgeon-robot architecture based on the robot-assistant concept and a navigation system capable of managing brain shifts. Thus, the challenges they pursue are based on tracking trajectories that interact with deformable tissues, the combination of real and virtual images to manage brain shift and the identification of the procedure workflow. All these challenges are grouped into a "co-worker" robot scheme in which the key is human-machine collaboration and the learning of the latter as it accumulates experience in working with the surgeon.

On the other hand, the University of Calgary, Canada, has its own novel robotic platform (NeuroArm) for microneurosurgery that is compatible with iMRI. According to promising results with its first case studies [19], such platform requires short-term additional clinical studies to determine the feasibility of integrating robotics into the workflow of micro neurosurgery.

In [84], Kuhl and her team at Stanford University propose pose different research and medium and long-term efforts to provide neurosurgeons with new tools. The latter include computational simulations of anatomically realistic brain tissue behavior (which requires an interdisciplinary approach combining the fields of 
mathematical physical modeling, scientific computation and medical imaging) along with contour conditions and under different loads that enable to look inside the brain and make more informed decisions. Therefore, the development of a computationally efficient numerical model with high capacity to predict deformations remains a significant challenge [85]. In [86], Broggi, a neurosurgeon and professor at Carlo Besta Neurological Institute in Milan, Italy-based on his years of experience with a variety of approaches to understand and treat the human brainbelieves that the future of neurosurgery in the short and medium-term is the validation of and experimentation with new assistance technologies that support current neurosurgical procedures and make use of robotics and virtual reality. Likewise, the trend of technological progress points towards the development of miniaturized, cost-effective and more intuitive robotic solutions, [3] and [35]. In the future of neurosurgery, with possible advances, hypothetical approaches could be planned to ensure minimal invasion during medical procedures that take into account the restriction of movements and optimization of brain shift effects [67], [69] and [73]. Finally, although it is known that intraoperative magnetic resonance imaging or computed tomography improve the precision of guided neurosurgical procedures, few studies have examined the cost-benefit of these expensive systems, leading to a new field of study and analysis in neurosurgery, [16] and [87].

\section{CONCLUSIONS}

This article presents the state of the art of neurosurgery, the contribution of current robotic systems for assisting the surgeon, and the problems and solutions proposed to the challenge imposed by brain shift. There are several scientific challenges in the development of this field and, in the future, the inclusion of miniaturized robotic tools in surgical procedures is inferred.

The most significant limitation to neuronavigation during surgery is the loss of correlation between the preoperative 3D model and the surgical probe, due to the brain shift phenomenon. Thus, neuronavigation systems that include the ability to compensate for brain shift and, therefore, improve the accuracy of neurosurgical procedures in a cost-effective way are likely to be the next breakthrough in image-guided neurosurgery.

The introduction of robotics in neurosurgery and the assistance of new imaging techniques enable a more precise identification and location of surgical targets. This situation leads to a more complete removal of pathologies and helps to avoid important damage to neural structures, which results in a decrease in patient morbidity and mortality.

\section{REFERENCES}

[1] P. B. McBeth, D. F. Louw, P. R. Rizun, and G. R. Sutherland, "Robotics in neurosurgery," Am. J. Surg., vol. 188, no. 4, pp. 6875, Oct. 2004.

[2] S. Nicolaidis, "Neurosurgery of the future: Deep brain stimulations and manipulations," Metabolism, vol. 69, pp. S16-S20, Apr. 2017.

[3] C. Faria, W. Erlhagen, M. Rito, E. De Momi, G. Ferrigno, and E. Bicho, "Review of Robotic Technology for Stereotactic Neurosurgery," IEEE Rev. Biomed. Eng., vol. 8, pp. 125-137, 2015.

[4] M. I.-P. H. Cobb, J. M. Taekman, A. R. Zomorodi, L. F. Gonzalez, and D. A. Turner, "Simulation in Neurosurgery-A Brief Review and Commentary," World Neurosurg., vol. 89, pp. 583-586, May 2016.

[5] A. N. Kumar, M. I. Miga, T. S. Pheiffer, L. B. Chambless, R. C. Thompson, and B. M. Dawant, "Persistent and automatic intraoperative 3D digitization of surfaces under dynamic magnifications of an operating microscope," Med. Image Anal., vol. 19, no. 1, pp. 30-45, Jan. 2015.

[6] S. Budday, R. Nay, R. de Rooij, P. Steinmann, T. Wyrobek, T. C. Ovaert, and E. Kuhl, "Mechanical properties of gray and 
white matter brain tissue by indentation," $J$. Mech. Behav. Biomed. Mater., vol. 46, pp. 318-330, Jun. 2015.

[7] A. Goriely, M. G. D. Geers, G. A. Holzapfel, J. Jayamohan, A. Jérusalem, S. Sivaloganathan, W. Squier, J. A. W. van Dommelen, S. Waters, and E. Kuhl, "Mechanics of the brain: perspectives, challenges, and opportunities," Biomech. Model. Mechanobiol., vol. 14, no. 5, pp. 931-965, Oct. 2015.

[8] I. Reinertsen, F. Lindseth, C. Askeland, D. H. Iversen, and G. Unsgård, "Intra-operative correction of brain-shift," Acta Neurochir. (Wien)., vol. 156, no. 7, pp. 1301-1310, Jul. 2014.

[9] R. R. Shamir, L. Joskowicz, I. Tamir, E. Dabool, L. Pertman, A. Ben-Ami, and Y. Shoshan, "Reduced risk trajectory planning in image-guided keyhole neurosurgery," Med. Phys., vol. 39, no. 5, pp. 2885-2895, May 2012.

[10] G. Echegaray, I. Herrera, I. Aguinaga, C. Buchart, and D. Borro, "A Brain Surgery Simulator," IEEE Comput. Graph. Appl., vol. 34, no. 3, pp. 12-18, May 2014.

[11] D. Hu, Y. Gong, B. Hannaford, and E. J. Seibel, "Path planning for semi-automated simulated robotic neurosurgery," in 2015 IEEE/RSJ International Conference on Intelligent Robots and Systems (IROS), 2015, pp. 2639-2645.

[12] S. Bano, Seong Young Ko, and F. Rodriguez y Baena, "Smooth path planning for a biologically-inspired neurosurgical probe," in 2012 Annual International Conference of the IEEE Engineering in Medicine and Biology Society, 2012, pp. 920-923.

[13] B. J. Mohammed, A. M. Abbosh, S. Mustafa, and D. Ireland, "Microwave System for Head Imaging," IEEE Trans. Instrum. Meas., vol. 63, no. 1, pp. 117-123, Jan. 2014.

[14] D. Paraskevopoulos, J. Roth, and S. Constantini, "Endoscope Holders in Cranial Neurosurgery: Part I-Technology, Trends, and Implications," World Neurosurg. vol. 89, pp. 343-354, May 2016.

[15] R. Reisch, A. Stadie, R. A. Kockro, and N. Hopf, "The Keyhole Concept in Neurosurgery," World Neurosurg. vol. 79, no. 2, p. S17.e9-S17.e13, Feb. 2013.

[16] N. W. D. Thomas and J. Sinclair, "ImageGuided Neurosurgery: History and Current Clinical Applications," J. Med. Imaging Radiat. Sci., vol. 46, no. 3, pp. 331-342, Sep. 2015.

[17] P. Yashar and L. N. Hopkins, "Instrumentation in Neurosurgery: Nurturing the Trend toward Minimalism," World Neurosurg. vol. 80, no. 3-4, pp. 240-242, Sep. 2013.
[18] D. Liu and T. Wang, "A Workflow for Robot Assisted Neurosurgery," in 2006 IEEE/RSJ International Conference on Intelligent Robots and Systems, 2006, pp. 2870-2875.

[19] A. E. Ibrahim, K. A. Sarhane, and J. C. Selber, "New Frontiers in Robotic-Assisted Microsurgical Reconstruction," Clin. Plast. Surg., vol. 44, no. 2, pp. 415-423, Apr. 2017.

[20] J. A. M. Padilla, J. B. Coll, and D. M. Rosito, "Neurocirugía endoscópica, la nueva era," El Resid., vol. 4, no. 2, pp. 67-72, 2009.

[21] R. Rehder and A. R. Cohen, "EndoscopeAssisted Microsurgical Subtemporal Keyhole Approach to the Posterolateral Suprasellar Region and Basal Cisterns," World Neurosurg. vol. 103, pp. 114-121, Jul. 2017.

[22] V. Trévillot, R. Garrel, E. Dombre, P. Poignet, R. Sobral, and L. Crampette, "Robotic endoscopic sinus and skull base surgery: Review of the literature and future prospects," Eur. Ann. Otorhinolaryngol. Head Neck Dis., vol. 130, no. 4, pp. 201-207, Sep. 2013.

[23] R. L. Carrau, D. M. Prevedello, D. de Lara, K. Durmus, and E. Ozer, "Combined transoral robotic surgery and endoscopic endonasal approach for the resection of extensive malignancies of the skull base," Head Neck, vol. 35, no. 11, pp. E351-E358, Nov. 2013.

[24] R. Wirz, L. G. Torres, P. J. Swaney, H. Gilbert, R. Alterovitz, R. J. Webster, K. D. Weaver, and P. T. Russell, "An Experimental Feasibility Study on Robotic Endonasal Telesurgery," Neurosurgery, vol. 76, no. 4, pp. 479484, Apr. 2015.

[25] M. Sadeghi-Goughari and A. Mojra, "Intraoperative thermal imaging of brain tumors using a haptic-thermal robot with application in minimally invasive neurosurgery," Appl. Therm. Eng., vol. 91, pp. 600610, Dec. 2015

[26] Oscar Andrés Vivas Albán, "Aplicaciones de la robotica al campo de la medicina," 2007.

[27] J. Weickenmeier, E. Kuhl, and A. Goriely, "The mechanics of decompressive craniectomy: Bulging in idealized geometries," $J$. Mech. Phys. Solids, vol. 96, pp. 572-590, Nov. 2016.

[28] K. M. Labus and C. M. Puttlitz, "Viscoelasticity of brain corpus callosum in biaxial tension," J. Mech. Phys. Solids, vol. 96, pp. 591604, Nov. 2016.

[29] A. N. Kumar, M. I. Miga, T. S. Pheiffer, L. B. Chambless, R. C. Thompson, and B. M. Dawant, "Automatic tracking of intraoperative brain surface displacements in brain tumor surgery," in 2014 36th Annual International Conference of the IEEE Engineering in Medicine and Biology Society, 2014, pp. 1509-1512. 
[30] Gang Li, Hao Su, G. A. Cole, Weijian Shang, K. Harrington, A. Camilo, J. G. Pilitsis, and G. S. Fischer, "Robotic System for MRIGuided Stereotactic Neurosurgery," IEEE Trans. Biomed. Eng., vol. 62, no. 4, pp. 10771088, Apr. 2015.

[31] H. Yousefi, "An Optimised Linear Mechanical Model for Estimating Brain Shift Caused by Meningioma Tumours," Int. J. Biomed. Sci. Eng., vol. 1, no. 1, p. 1, 2013.

[32] G. Soza, R. Grosso, C. Nimsky, P. Hastreiter, R. Fahlbusch, and G. Greiner, "Determination of the elasticity parameters of brain tissue with combined simulation and registration," Int. J. Med. Robot. Comput. Assist. Surg., vol. 1, no. 3, pp. 87-95, Sep. 2005.

[33] P. J. Hutchinson, A. G. Kolias, I. S. Timofeev, E. A. Corteen, M. Czosnyka, J. Timothy, I. Anderson, D. O. Bulters, A. Belli, C. A. Eynon, J. Wadley, A. D. Mendelow, P. M. Mitchell, M. H. Wilson, G. Critchley, J. Sahuquillo, A. Unterberg, F. Servadei, G. M. Teasdale, J. D. Pickard, D. K. Menon, G. D. Murray, and P. J. Kirkpatrick, "Trial of Decompressive Craniectomy for Traumatic Intracranial Hypertension," N. Engl. J. Med., vol. 375 , no. 12 , pp. 1119-1130, Sep. 2016.

[34] T. Hartkens, D. L. G. Hill, A. D. CastellanoSmith, D. J. Hawkes, C. R. Maurer, A. J. Martin, W. A. Hall, H. Liu, and C. L. Truwit, "Measurement and analysis of brain deformation during neurosurgery," IEEE Trans. Med. Imaging, vol. 22, no. 1, pp. 82-92, Jan. 2003.

[35] A. Shaikhouni and J. B. Elder, "Computers and Neurosurgery," World Neurosurg. vol. 78, no. 5, pp. 392-398, Nov. 2012.

[36] D. B. Camarillo, T. M. Krummel, and J. K. Salisbury, "Robotic technology in surgery: Past, present, and future," Am. J. Surg., vol. 188, no. 4, pp. 2-15, Oct. 2004.

[37] T. L. Cossetto, K. Zareinia, and G. R. Sutherland, "Robotics for neurosurgery," in Medical Robotics, P. Gomes, Ed. Woodhead Publishing, 2012, pp. 59-77.

[38] Y. S. Chae, S. H. Lee, H. M. Oh, and M. Y. Kim, "Coordinates tracking and augmented reality system using bipolar X-ray fluoroscopy and stereo vision for image-guided neurosurgery," in 2013 13th International Conference on Control, Automation and Systems (ICCAS 2013), 2013, pp. 107-112.

[39] G. R. Sutherland, I. Latour, and A. D. Greer, "Integrating an Image-Guided Robot with Intraoperative MRI," IEEE Eng. Med. Biol. Mag., vol. 27, no. 3, pp. 59-65, May 2008.

[40] M. D. Comparetti, E. De Momi, A. Vaccarella, M. Riechmann, and G. Ferrigno, "Optically tracked multi-robot system for keyhole neurosurgery," in 2011 IEEE International
Conference on Robotics and Automation, 2011, pp. 661-666.

[41] D. P. Devito, L. Kaplan, R. Dietl, M. Pfeiffer, D. Horne, B. Silberstein, M. Hardenbrook, G. Kiriyanthan, Y. Barzilay, A. Bruskin, D. Sackerer, V. Alexandrovsky, C. Stüer, R. Burger, J. Maeurer, D. G. Gordon, R. Schoenmayr, A. Friedlander, N. Knoller, K. Schmieder, I. Pechlivanis, I.-S. Kim, B. Meyer, and M. Shoham, "Clinical Acceptance and Accuracy Assessment of Spinal Implants Guided With SpineAssist Surgical Robot," Spine (Phila. Pa. 1976)., vol. 35, no. 24, pp. 2109-2115, Nov. 2010.

[42] D. V. Amin and L. D. Lunsford, "Volumetric Resection Using the SurgiScope ${ }^{\circledR}$ : A Quantitative Accuracy Analysis of Robot-Assisted Resection," Stereotact. Funct. Neurosurg., vol. 82, no. 5-6, pp. 250-253, Feb. 2005.

[43] Q. H. Li, L. Zamorano, A. Pandya, R. Perez, J. Gong, and F. Diaz, "The application accuracy of the NeuroMate robot - A quantitative comparison with frameless and frame-based surgical localization systems," Comput. Aided Surg., vol. 7, no. 2, pp. 90-98, 2002.

[44] J. Gonzalez-Martinez, S. Vadera, J. Mullin, R. Enatsu, A. V Alexopoulos, R. Patwardhan, W. Bingaman, and I. Najm, "Robot-Assisted Stereotactic Laser Ablation in Medically Intractable Epilepsy," Oper. Neurosurg., vol. 10, no. 2, pp. 167-173, Jun. 2014.

[45] L. M. Auer, S. Starkie, D. P. Auer, and B. Davies, "Simulating minimally invasive neurosurgical interventions using an active manipulator," Int. Congr. Ser., vol. 1247, pp. 199-210, Dec. 2002.

[46] G. Deacon, A. Harwood, J. Holdback, D. Maiwand, M. Pearce, I. Reid, M. Street, and J. Taylor, "The Pathfinder image-guided surgical robot," Proc. Inst. Mech. Eng. Part H J. Eng. Med., vol. 224, no. 5, pp. 691-713, May 2010.

[47] C. Nimsky, J. Rachinger, H. Iro, and R. Fahlbusch, "Adaptation of a Hexapod-Based Robotic System for Extended EndoscopeAssisted Transsphenoidal Skull Base Surgery," min - Minim. Invasive Neurosurg., vol. 47, no. 1, pp. 41-46, Feb. 2004.

[48] K. Bekelis, T. A. Radwan, A. Desai, and D. W. Roberts, "Frameless robotically targeted stereotactic brain biopsy: feasibility, diagnostic yield, and safety," J. Neurosurg., vol. 116, no. 5, pp. 1002-1006, May 2012.

[49] J. Hao, X. Xie, G.-B. Bian, Z.-G. Hou, and X.H. Zhou, "Development of a multi-modal interactive system for Endoscopic Endonasal Approach surgery simulation," in 2016 IEEE International Conference on Robotics and Biomimetics (ROBIO), 2016, pp. 143-148. 
[50] L. Zrinzo, "Pitfalls in precision stereotactic surgery," Surg. Neurol. Int., vol. 3, no. 2, p. $53,2012$.

[51] H. J. Marcus, C. A. Seneci, C. J. Payne, D. Nandi, A. Darzi, and G.-Z. Yang, "Robotics in Keyhole Transcranial Endoscope-Assisted Microsurgery," Oper. Neurosurg., vol. 10, no. 1, pp. 84-96, Mar. 2014.

[52] T. A. Mattei, A. H. Rodriguez, D. Sambhara, and E. Mendel, "Current state-of-the-art and future perspectives of robotic technology in neurosurgery," Neurosurg. Rev., vol. 37, no. 3, pp. 357-366, 2014.

[53] M. N. Huda, H. Yu, and S. Cang, "Robots for minimally invasive diagnosis and intervention," Robot. Comput. Integr. Manuf., vol. 41, pp. 127-144, Oct. 2016.

[54] C. DeLorenzo, X. Papademetris, L. H. Staib, K. P. Vives, D. D. Spencer, and J. S. Duncan, "Volumetric Intraoperative Brain Deformation Compensation: Model Development and Phantom Validation," IEEE Trans. Med. Imaging, vol. 31, no. 8, pp. 1607-1619, Aug. 2012.

[55] I. Chen, R. E. Ong, A. L. Simpson, K. Sun, R. C. Thompson, and M. I. Miga, "Integrating Retraction Modeling Into an Atlas-Based Framework for Brain Shift Prediction," IEEE Trans. Biomed. Eng., vol. 60, no. 12, pp. 3494-3504, Dec. 2013.

[56] M. Oldfield, D. Dini, G. Giordano, and F. Rodriguez y Baena, "Detailed finite element modelling of deep needle insertions into a soft tissue phantom using a cohesive approach," Comput. Methods Biomech. Biomed. Engin., vol. 16, no. 5, pp. 530-543, May 2013.

[57] L. W. Clements, J. A. Collins, J. A. Weis, A. L. Simpson, L. B. Adams, W. R. Jarnagin, and M. I. Miga, "Evaluation of model-based deformation correction in image-guided liver surgery via tracked intraoperative ultrasound," J. Med. Imaging, vol. 3, no. 1, p. 15003, Mar. 2016.

[58] M. Schulder and P. W. Carmel, "Intraoperative magnetic resonance imaging: impact on brain tumor surgery." Cancer Control, vol. 10, no. 2, pp. 115-24, 2003.

[59] N. Nakao, K. Nakai, and T. Itakura, "Updating of Neuronavigation Based on Images Intraoperatively Acquired with a Mobile Computerized Tomographic Scanner: Technical Note," min - Minim. Invasive Neurosurg., vol. 46, no. 2, pp. 117-120, Apr. 2003.

[60] D. G. Gobbi, R. M. Comeau, and T. M. Peters, "Ultrasound/MRI Overlay with Image Warping for Neurosurgery," in Medical Image Computing and Computer-Assisted Intervention--MICCAI 2000, 2000, pp. 29-53.

[61] S. Mittal and P. M. Black, "Intraoperative magnetic resonance imaging in neurosur- gery: the Brigham concept." Acta Neurochir. Suppl., vol. 98, pp. 77-86, 2006.

[62] H. O. Yegingil, "Breast cancer detection and differentiation using piezoelectric fingers," 2009.

[63] R. Fahlbusch and A. Samii, "A review of cranial imaging techniques: potential and limitations." Clin. Neurosurg., vol. 54, pp. 100-4, 2007.

[64] M. M. J. Letteboer, P. W. A. Willems, M. A. Viergever, and W. J. Niessen, "Brain Shift Estimation in Image-Guided Neurosurgery Using 3-D Ultrasound," IEEE Trans. Biomed. Eng., vol. 52, no. 2, pp. 268-276, Feb. 2005.

[65] P. Coupe, P. Hellier, X. Morandi, and C. Barillot, "Intraoperative ultrasonography for the correction of brainshift based on the matching of hyperechogenic structures," in 2010 IEEE International Symposium on Biomedical Imaging: From Nano to Macro, 2010, pp. 1405-1408.

[66] C. E. Uff, L. Garcia, J. Fromageau, N. Dorward, and J. C. Bamber, "Real-time ultrasound elastography in neurosurgery," in 2009 IEEE International Ultrasonics Symposium, 2009, pp. 467-470.

[67] J. Weickenmeier, C. A. M. Butler, P. G. Young, A. Goriely, and E. Kuhl, "The mechanics of decompressive craniectomy: Personalized simulations," Comput. Methods Appl. Mech. Eng., vol. 314, pp. 180-195, Feb. 2017.

[68] A. Mohammadi, A. Ahmadian, S. Rabbani, E. Fattahi, and S. Shirani, "A combined registration and finite element analysis method for fast estimation of intraoperative brain shift; phantom and animal model study," Int. J. Med. Robot. Comput. Assist. Surg., 2016.

[69] A. Mohammadi, A. Ahmadian, A. D. Azar, A. D. Sheykh, F. Amiri, and J. Alirezaie, "Estimation of intraoperative brain shift by combination of stereovision and doppler ultrasound: phantom and animal model study," Int. J. Comput. Assist. Radiol. Surg., vol. 10, no. 11 , pp. 1753-1764, Nov. 2015.

[70] M. I. Miga, K. Sun, I. Chen, L. W. Clements, T. S. Pheiffer, A. L. Simpson, and R. C. Thompson, "Clinical evaluation of a modelupdated image-guidance approach to brain shift compensation: experience in 16 cases," Int. J. Comput. Assist. Radiol. Surg., vol. 11, no. 8, pp. 1467-1474, Aug. 2016.

[71] N. Hamze, A. Bilger, C. Duriez, S. Cotin, and C. Essert, "Anticipation of brain shift in Deep Brain Stimulation automatic planning," in 2015 37th Annual International Conference of the IEEE Engineering in Medicine and Biology Society (EMBC), 2015, pp. 3635-3638. 
[72] A. L. Simpson, Kay Sun, T. S. Pheiffer, D. C. Rucker, A. K. Sills, R. C. Thompson, and M. I. Miga, "Evaluation of Conoscopic Holography for Estimating Tumor Resection Cavities in Model-Based Image-Guided Neurosurgery," IEEE Trans. Biomed. Eng., vol. 61, no. 6, pp. 1833-1843, Jun. 2014.

[73] Kay Sun, T. S. Pheiffer, A. L. Simpson, J. A. Weis, R. C. Thompson, and M. I. Miga, "Near Real-Time Computer Assisted Surgery for Brain Shift Correction Using Biomechanical Models," IEEE J. Transl. Eng. Heal. Med., vol. 2, pp. 1-13, 2014.

[74] N. D. Serej, A. Ahmadian, S. Mohagheghi, and S. M. Sadrehosseini, "A projected landmark method for reduction of registration error in image-guided surgery systems," Int. J. Comput. Assist. Radiol. Surg., vol. 10, no. 5, pp. 541-554, May 2015.

[75] G. R. Joldes, A. Wittek, and K. Miller, "Realtime nonlinear finite element computations on GPU - Application to neurosurgical simulation," Comput. Methods Appl. Mech. Eng., vol. 199, no. 49-52, pp. 3305-3314, Dec. 2010.

[76] Chenxi Zhang, Manning Wang, and Zhijian Song, "A Brain-Deformation Framework Based on a Linear Elastic Model and Evaluation Using Clinical Data," IEEE Trans. Biomed. Eng., vol. 58, no. 1, pp. 191-199, Jan. 2011.

[77] M. Bucki, O. Palombi, M. Bailet, and Y. Payan, "Doppler ultrasound driven biomechanical model of the brain for intraoperative brain-shift compensation: a proof of concept in clinical conditions," in Soft tissue biomechanical modeling for computer assisted surgery, Springer, 2012, pp. 135-165.

[78] D.-X. Zhuang, Y.-X. Liu, J.-S. Wu, C.-J. Yao, Y. Mao, C.-X. Zhang, M.-N. Wang, W. Wang, and L.-F. Zhou, "A Sparse Intraoperative Data-Driven Biomechanical Model to Compensate for Brain Shift during Neuronavigation," Am. J. Neuroradiol., vol. 32, no. 2, pp. 395-402, Feb. 2011.
[79] S. Budday, P. Steinmann, and E. Kuhl, "The role of mechanics during brain development," J. Mech. Phys. Solids, vol. 72, pp. 75-92, Dec. 2014.

[80] R. de Rooij and E. Kuhl, "Constitutive Modeling of Brain Tissue: Current Perspectives," Appl. Mech. Rev., vol. 68, no. 1, p. 10801, Jan. 2016.

[81] S. A. Kruse, G. H. Rose, K. J. Glaser, A. Manduca, J. P. Felmlee, C. R. Jack, and R. L. Ehman, "Magnetic resonance elastography of the brain," Neuroimage, vol. 39, no. 1, pp. 231-237, Jan. 2008.

[82] A. Fukuhara, T. Tsujita, K. Sase, A. Konno, X. Jiang, S. Abiko, and M. Uchiyama, "Optimization of retraction in neurosurgery to avoid damage caused by deformation of brain tissues," in 2014 IEEE International Conference on Robotics and Biomimetics (ROBIO 2014), 2014, pp. 588-594.

[83] Hang Zhou and H. Rivaz, "Robust deformable registration of pre- and post-resection ultrasound volumes for visualization of residual tumor in neurosurgery," in 2015 37th Annual International Conference of the IEEE Engineering in Medicine and Biology Society (EMBC), 2015, pp. 141-144.

[84] J. Weickenmeier, P. Saez, C. A. M. Butler, P. G. Young, A. Goriely, and E. Kuhl, "Bulging Brains," J. Elast., vol. 129, no. 1-2, pp. 1-16, Dec. 2017.

[85] S. Budday, P. Steinmann, and E. Kuhl, "Physical biology of human brain development," Front. Cell. Neurosci., vol. 9, Jul. 2015.

[86] G. Broggi, "A Journey in Neurosurgery," World Neurosurg. vol. 80, no. 1-2, pp. 28-38, Jul. 2013.

[87] W. A. Hall and C. L. Truwit, "Intraoperative MR-guided neurosurgery," J. Magn. Reson. Imaging, vol. 27, no. 2, pp. 368-375, Feb. 2008. 